\title{
Flotation tests with a mix of two natural oils as apatite collectors
}

\begin{abstract}
It is essential to use natural, non-polluting and low-cost reagents in froth flotation in order to achieve a more sustainable and environmentally friendly process in mineral industry. Therefore, flotation tests in Hallimond tube were carried out with high purity apatite crystals using a mixture of a Brazilian fruit (Macaúba) and seed oil (Jatropha Curcas). The tests were carried out at $\mathrm{pH} 8$, using a collector dosage of $2.5 \mathrm{mg} / \mathrm{L}$. The oils were mixed at five different ratios $(0: 100,25: 75,50: 50,75: 25$, and 100:0). The synthetic fatty acid mix called Flotigam 5806, from Clariant, an industrially adopted collector was used as benchmark. Macaúba oil, which is the richest in oleic acid, promoted floatability of apatite similar to Flotigam 5806 (almost 92\%) and quite superior to Jatropha oil. One explanation for the low performance of collector based on pure Jatropha oil could be due to its lower content of oleic acid. However, since the Jatropha oil has a lower cost than Macaúba oil, the resulting mixture of the two oils in a ratio of 90:10 (Macaúba: Jatropha) promoted the reduction of collector final cost (8\% lower than pure Macaúba oil and $44 \%$ lower than Flotigam 5806) while maintaining the floatability of apatite similar to Flotigam 5806 and pure Macaúba oil. However, prior to application at industrial scale it is recommended to use more laboratory tests using real ore from the plant.
\end{abstract}

Keywords: microflotation, natural fatty acids, macaúba pulp oil, jatropha curcas oil, apatite
Volume 4 Issue 5 - 2020

\section{André Carlos SILVA, Ana Luiza Sampaio \\ AMORIM, Elenice Maria Schons SILVA, \\ Ramon Vinhas Oliveira LIMA, Carlos \\ Eduardo Domingues da MATA \\ Federal University of Goiás, Brazil}

\begin{abstract}
Correspondence: André Carlos SILVA, Federal University of Goiás, LaMPPMin, 08 street 25, Catalão/GO, 75705-32I, Brazil, Tel +55 64 984038716, Email ancarsil@ufg.br
\end{abstract}

Received: December 18, 2019 | Published: October 28, 2020

\section{Introduction}

Phosphate deposits are classified according to the genesis process as sedimentary, igneous or biogenic deposits. Most of the Brazilian reserves (about $80 \%$ ) are from igneous formations. Apatite is the most common phosphate mineral $\left[\mathrm{Ca}_{5}(\mathrm{Cl}, \mathrm{F}, \mathrm{OH})\left(\mathrm{PO}_{4}\right)_{3}\right]$ and the main raw material to produce fertilizers based on phosphorus. The achievement of $\mathrm{P}_{2} \mathrm{O}_{5}$ grade required to the next steps of purification processes (wet chemical methods) is performed through direct anionic flotation process in Brazil's ore beneficiation plants. Flotation is a concentration process based on the characteristics of hydrophobicity and hydrophilicity of the particles (interfacial differentiating property).
Collectors are flotation reagents used to hydrophilizing selectively the surface of the targeted mineral particles, in order to allow the contact and adhesion between the particles and air bubbles that are recovered in the froth. ${ }^{1}$ Salts of fatty acids extracted from vegetable oils are the most common collectors used in the direct anionic flotation of apatite. A problematic issue concerning phosphate flotation using fatty acids as collectors is the low selectivity between apatite and carbonates (commonly associated with alkaline carbonatitic complexes) surface, due to the presence of similar cations sites in both crystalline structures. This fact influencing negatively the efficiency of the flotation process. ${ }^{2}$

Table I Fatty acids composition (\%) of Macaúba and Jatropha Curcas oils

\begin{tabular}{|c|c|c|c|c|}
\hline \multirow{2}{*}{$\begin{array}{l}\text { Content of fatty acids } \\
\text { (wt\%) }\end{array}$} & \multicolumn{3}{|l|}{ Macaúba } & \multirow{2}{*}{$\begin{array}{l}\text { Jatropha curcas } \\
\text { Silva et al. } .^{10}\end{array}$} \\
\hline & Fortes \& Baugh ${ }^{6}$ & Zuppa $^{7}$ & Ciconini $^{8}$ & \\
\hline Caprylic (C8) & 0,8 & 0,45 & - & - \\
\hline Capric $(\mathrm{ClO})$ & 0,5 & 0,27 & - & - \\
\hline Lauric $(\mathrm{Cl} 2)$ & 3,8 & $\mathrm{I}, 97$ & 2,93 & - \\
\hline Myristic (Cl4) & $\mathrm{I}, \mathrm{I}$ & 0,45 & 1,88 & - \\
\hline Palmitic $(\mathrm{Cl} 6)$ & 19,7 & 15,96 & 22,3 & 19,6 \\
\hline Estearic (Cl8) & 2 & 5,92 & 5,75 & 9,6 \\
\hline Arachidonic (C20) & 0,2 & 0,5 & - & 0,3 \\
\hline Gadoleic (C20:I) & 0,1 & - & - & - \\
\hline Palmitoleic (CI6:I) & 2,8 & $\mathrm{I}, 0 \mathrm{I}$ & 5,28 & 2,4 \\
\hline Oleic (CI8:I) & 58,7 & 65,87 & 58,82 & 33,96 \\
\hline Linoleic (CI8:2) & 7,3 & 5,1 & 4,69 & 42,88 \\
\hline Vacenic (CI8:2) & 1,9 & - & - & - \\
\hline Linolenic (CI8:3) & $\mathrm{I}, \mathrm{I}$ & 2,52 & - & - \\
\hline
\end{tabular}


Vegetable oils are often targeting of researches aiming to investigate its potential as collectors, seeking alternative reagents that offer greater selectivity in flotation. Some Brazilian fruits and cereals have already been objects of research, as can be seen in the study of Costa ${ }^{3}$ which obtained satisfactory results in phosphate flotation using vegetable oils of Amazon rainforest's native fruits. Macaúba (Acrocomia aculeata) is a palm tree typical of tropical regions in Latin America, and it has overall application as raw material for pharmaceuticals, furniture, handicrafts, food industry and production of biofuels. In addition, the co-products generated in the extraction process of Macaúba oil can be used in the composition of animal feed and the production of charcoal. ${ }^{4}$ Jatropha Curcas is a shrub and oilseed plant resistant to climatic variations. It used to be raw material on the production of biofuel in pilot scale plants in Brazil. ${ }^{5}$ Table 1 shows the lipid composition of oils extracted from different sources of Macaúba as determinated by Fortes and Baugh ${ }^{6} \& \mathrm{Zuppa}^{7} \& \mathrm{Ciconini}^{8}$, as well as the Jatropha Curcas composition measured by Silva et $\mathrm{al}^{5}$ for comparison purposes. The high content of saturated fatty acids in the oil adversely affects the adsorption of the reagent on the targeted mineral surface and, consequently, the flotation efficiency.

Pachêco et $\mathrm{al}^{9}$ remarked quite favorable results related to the applicability and efficacy of Macaúba oil as an apatite collector, as well as Silva et $\mathrm{al}^{5}$ attested the effectiveness, in this case, of Jatropha Curcas oil for this purpose. In order to develop natural, non-polluting and low-cost reagents in froth flotation process, the performance of a blend of Macaúba (MACO) and Jatropha Curcas (JCO) oils in different proportions as apatite collector in direct flotation was evaluated. The costing of reagents and floatability of apatite (\%) promoted by the oils tested was compared to a synthetic fatty acid mix called Flotigam 5806, from Clariant, an industrially adopted collector used as benchmark.

\section{Material and methods}

\section{Material}

Blue crystals of igneous apatite from Ipirá-BA, Brazil, were processed using a methodology proposed by Silva et $\mathrm{al}^{10}$ in which the samples were comminuted in a jaw crusher followed by a ball mill, and granulometrically separated using wet sieving in a Tyler sieving series for 15 minutes. The samples were then dried in an oven at $60^{\circ} \mathrm{C}$ for 24 hours. A ferrite magnet with field strength of $2 \mathrm{kG}$ was used to remove any possible contamination from the previous stages. The same authors performed the apatite samples mineralogical characterization. Apatite samples at the size range of $+149-177 \mu \mathrm{m}(+100-80$ \#) were used in the micro flotation tests. Macaúba oil (MACO) was purchased from farmers of the Coco Macaúba Processing Unit (UBCM) by the Riacho D'antas Macaúba Association, located in the city of Montes Claros, and the Jatropha Curcas' oil (JCO) was donated by Embrapa Brasília unit. Flotigam 5806 provided by Clariant, a synthetic mix of fatty acids, was used as collector benchmark. Hydrochloric acid and sodium hydroxide, both at $1 \%$ concentration, were used as $\mathrm{pH}$ modifier. Distilled water was used throughout the experiments.

\section{Method}

The collectors tested were saponified at room temperature. The oils were mixed (MACO:JCO) at five different ratios in weight $(0: 100$, $25: 75,50: 50,75: 25$, and 100:0). The oils blending in the proposed weight ratio was carried out before the saponification procedure. Prior to flotation tests in Hallimond tube is essential to perform the saponification procedure in alkaline medium in order to establish the fatty acids as soluble salts in water, improving its collecting effect.
To perform the saponification procedure at room temperature was necessary to put on in a $250 \mathrm{~mL}$ beaker: $5.0 \mathrm{~g}$ of the collector, $20 \mathrm{~mL}$ of distilled water and $7.5 \mathrm{~mL}$ of $10 \%(\mathrm{w} / \mathrm{v}) \mathrm{NaOH}$ solution. The reagents were mixed for 5 minutes in a magnetic stirrer until entirely conversion of the oils to salts of fatty acids. After stopping the stirring process, more $100 \mathrm{~g}$ of distilled water were added to the beaker and stirred over again for 10 minutes in order to homogenize the solution. The synthetic collector Flotigam 5806, produced by Clariant, was saponified by the same procedure.

Table 2 Operational parameters of flotation tests

\begin{tabular}{ll}
\hline Test conditions & \\
\hline Airflow $\left(\mathrm{cm}^{3} / \mathrm{min}\right)$ & 40 \\
$\mathrm{pH}$ & 8,0 \\
Pressure $(\mathrm{psi})$ & 10 \\
Size range $(\mu \mathrm{m})$ & $-180+150$ \\
Mineral weight $(\mathrm{g})$ & 1,0 \\
Conditioning time $(\mathrm{min})$ & 7 \\
Flotation time $(\mathrm{min})$ & $\mathrm{I}$ \\
Collector dosage $(\mathrm{mg} / \mathrm{L})$ & 2,5 \\
Tube volume $(\mathrm{mL})$ & 320 \\
\hline
\end{tabular}

Table 3 Numerical optimization parameter

\begin{tabular}{llll}
\hline Optimization parameter & Minimum & Maximum & Criteria \\
\hline MACO (\%) & 0 & 100 & In range \\
JCO $(\%)$ & 0 & 100 & In range \\
Flotability $(\%)$ & 12.024 & 94.903 & Target $(>91)$ \\
Cost (US $\$$ L) & 0.26 & 1.29 & Minimize \\
\hline
\end{tabular}

The flotation tests were carried out in a $320 \mathrm{~mL}$ modified Hallimond tube, according to the conditions described in Table 2, using $1.0 \mathrm{~g}$ of the apatite sample and a collector dosage of $2.5 \mathrm{mg} / \mathrm{L}$ at $\mathrm{pH} 8$ for 7 minutes (conditioning time). After conditioning time, the airflow of $40 \mathrm{~cm}^{3} / \mathrm{min}$ and $10 \mathrm{psi}$ of pressure was opened in order to avoid hydrodynamic drag of the particles. Lastly, the floated and nonfloated products were vacuum filtered and dried in oven. The apatite's floatability (\%) was obtained through the calculation of material floated divided by total material fed ratio. All tests were performed in triplicates measurements for the same experimental conditions. With the flotation results, an optimization using a linear mixture model mixture was carried out using the StatEase ${ }^{\circledR}$ Design-Expert $\mathbb{}$ version 7.0.0. Table 3 presents the optimization parameters adopted. They were chosen aiming to minimize the blended collector cost and optimize the apatite floatability, considering a minimum floatability of $90 \%$.

\section{Results and discussion}

The apatite's floatability promoted in flotation tests using the natural oils blending at different proportions (red dots) and the Flotigam 5806 (dashed black line), both at concentration of $2.5 \mathrm{mg} / \mathrm{L}$, are shown in Figure 1. The test with pure MACO provided greater floatability (approximately 92\%) compared to blending with any proportion of JCO and similar to the Flotigam 5806 effect. Hence, the synergistic effect produced by increasing the proportion of JCO in the oil blending was unfavorable to the hydrophilization of apatite surface. Brandao et $\mathrm{al}^{11}$ conducted microflotation tests on Hallimond tube with pure apatite and observed that the unsaturated fatty acids (linoleic, oleic and linolenic) yielded substantially more hydrophilization effect on apatite surface than saturated fatty acids. A possible approach concerning the 
low performance of JCO confronting the MACO would be related to its lower content of oleic acid (33.96\%) as shown in Table 1 . However, this fact is not the only explanation to the low yield obtained with $\mathrm{JCO}$, once it is highly enriched in linoleic acid (42.88\%), which is also an effective collector for apatite as demonstrated by Brandao et $\mathrm{al}^{11}$. Mata ${ }^{12}$ also verified by carrying out microflotation tests of apatite and bench flotation tests with phosphate ore, using vegetable oils as collectors, that higher oleic/linoleic acid ratio on the oils compositions culminated in higher content and recovery of $\mathrm{P}_{2} \mathrm{O}_{5}$ in the concentrate. In addition, the MACO showed similar or slightly superior apatite's floatability compared to Flotigam 5806, which can also be observed in the work conducted by Pacheco ${ }^{13}$. Table 4 presents the ANOVA results for the apatite floatability the tested mixtures of MACO and JCO. The model F-value of 97.34 implies the adopted model is significant and there is only a $0.01 \%$ chance that a model F-Value this large could occur due to noise. Values of p-value less than 0.0500 indicate model terms are also significant. In this case, linear mixture components $\mathrm{AB}$ (being A the MACO and B the JCO percentage in the oil mixture) are significant model terms. The lack of fit F-value of 0.15 implies the lack of fit is not significant relative to the pure error (non-significant lack of fit is a good thing). There is an $86.43 \%$ chance that a lack of fit F-value this large could occur due to noise.

Table 4 ANOVA results for the apatite floatability using the mixtures of MACO and JCO

\begin{tabular}{lllllll}
\hline Source & Sum of squares & df & Mean square & F value & p-value (Prob $>$ F) & Result \\
Model & 10340.77 & 2 & 5170.383 & 97.33933 & $<0.0001$ & significant \\
Linear mixture & 10068.86 & $\mathrm{I}$ & 10068.86 & 189.5596 & $<0.0001$ & not significant \\
AB & 271.9094 & $\mathrm{I}$ & 271.9094 & 5.119056 & 0.0430 & \\
Residual & 637.4052 & 12 & 53.1171 & & & 0.8643 \\
Lack of fit & 18.32841 & 2 & 9.164205 & & & \\
Pure error & 619.0768 & 10 & 61.90768 & & & \\
Cor total & 10978.17 & 14 & & &
\end{tabular}

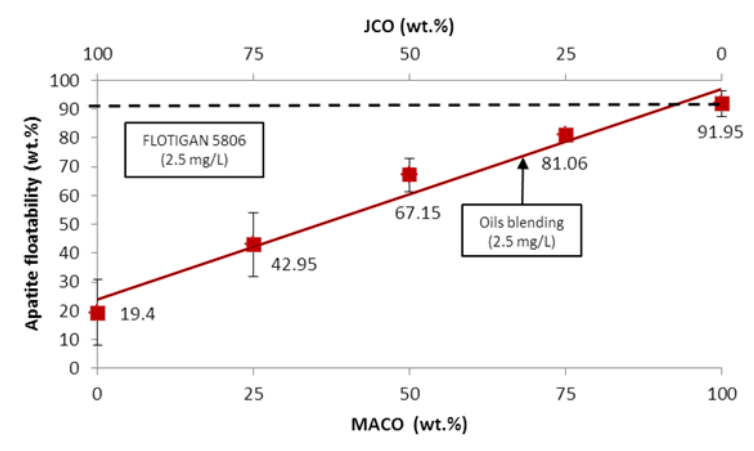

Figure I Apatite floatability (wt.\%) as a function of the MACO (wt.\%) in the collector blending (red line), compared to floatability promoted by Flotigam 5806 (dashed black line) at dosage of $2.5 \mathrm{mg} / \mathrm{L}$.

Regarding the economic approach, the estimated cost to produce JCO is approximately $\$ 0.26 / \mathrm{L}$, according to Bergmann et a ${ }^{14}$ who studied the Jatropha Curcas' crop productivity. On the other hand, in Pacheco ${ }^{9}$ survey was reported that MACO and Flotigam 5806 have a production cost of $\$ 1.29 / \mathrm{L}$ and $\$ 2.69 / \mathrm{L}$ respectively. Considering the low cost of JCO, it is plausible to assume that even admitting a drop in apatite's floatability, it would be possible to increase the cost-benefit of flotation by adding a bit of JCO in the collector composition. Hence, the linear regression (red line of Figure 1) was formulated based on the experimental data. Equation 1 describes the apatite's floatability $(\% \mathrm{FL})$ as a function of the MACO proportion (\%MACO) in the collector. The coefficient of determination $\left(\mathrm{R}^{2}\right)$ of $97.2 \%$ demonstrated that the linear model is quite fitted to experimental data.

$$
\% F L=0,73 . \% \text { MACO }+23,86
$$

The goal for apatite floatability was set at $90 \%$ for the determination of the optimal MACO: JCO ratio, resulting in a ratio of 90:10 calculated by the linear model of equation 1 . The cost (US\$/L) of each pure collector and the optimal blend of vegetable oils (90:10) are shown in the graphic of Figure 2. The optimal blend of MACO and JCO has the lowest cost (US\$1,18/L) among the collectors analyzed in Figure 2, 44\% lower than Flotigam 5806 and 8\% lower compared to pure MACO. In other words, an amount of $10 \%$ of JCO mixed with MACO reduces the collector cost at the same time preserving its efficiency. Therefore, the results imply the possibility of reduction in the costs of flotation, maintaining the same level of apatite's recovery, when using the blending oils instead the industrial collector (Flotigam 5806). Furthermore, additional bench scale and pilot flotation tests with phosphate ore are required to prove the technical-economic feasibility of using the blend of MACO and JCO as collectors.

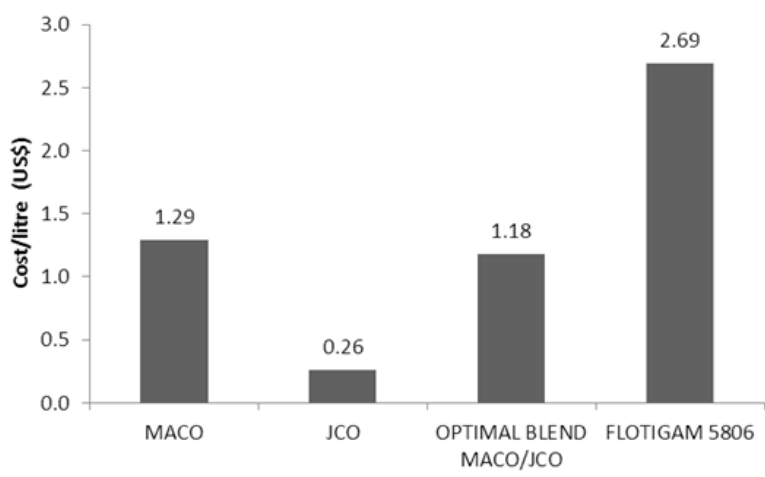

Figure 2 Cost (US\$/L) of the pure collectors and the optimal blend of MACO and $\mathrm{JCO}$ in the ratio of $90: 10$.

\section{Conclusion}

Macaúba pulp's oil, a fruit highly enriched in oleic acid (omega-9), typically found on the Brazilian savanna, locally known as cerrado, has an expressive capacity to adsorb and hydrophilizing the apatite surface. In terms of apatite's floatability, MACO is so efficient as the industrial collector Flotigam 5806, and has the advantages to be cheaper, natural and non-polluting reagent. On the other hand, pure JCO in this work did not show potential to be used as apatite's collector. 
Distribution of fatty acid in oils composition may have influenced the reagents performance, since MACO has more oleic acid than JCO. However, it is mandatory consider that JCO's cost is quite inferior to MACO, and for this reason, the mixture of the two oils in a ratio of 90:10 (MACO:JCO) imply in the final cost reduction of the collector (8\% lower than MACO and $44 \%$ lower than the Flotigam 5806) lossless of floatability. Nevertheless, prior to application at industrial scale it is recommended to use more laboratory tests (bench and pilot' flotation tests) using real ore from the plant. ${ }^{15-19}$

\section{Acknowledgments}

The authors thank financial support from the Brazilian agencies FAPEG, CNPq, CAPES, and FUNAPE. In addition, we would like to thank Embrapa - Brasilia/DF, LaMPPMin, and UFCAT.

\section{Conflicts of interest}

The author declares that there are no conflicts of interest.

\section{References}

1. Baltar CAM. Flotação no tratamento de minério. 2nd edn. Federal University of Pernambuco; 2009.

2. Albuquerque RO. Alternativas de Processo para concentração do minério fósforo-uranífero de Itataia. Brazil. Federal University of Minas Gerais; 2010:200

3. Costa DS. Uso de óleos vegetais amazônicos na flotação de minérios fosfáticos. Brazil. Federal University of Minas Gerais; 2012:176.

4. REMAPE - Macaúba Research Net. Industrialization and products. 2015.

5. Silva AC, Moraes ILA, Silva EMS, et al. Seletividade do óleo de pinhão manso (Jatropha Curcas L.) na microflotação de apatita, calcita e quartzo. Tecnologia em Metalurgia, Materiais e Mineração. 2018;15(3):341-349.

6. Fortes ICP, Baugh PJ. Study of analytical on-line pyrolysis of oils from Macaúba fruit (Acrocomia sclerocarpa M) via GC/MS. Journal of the Brazilian Chemical Society. 1999;10(6):469-477.

7. Zuppa T. Avaliação das potencialidades de plantas nativas e introduzidas no Cerrado na obtenção de óleos e gorduras vegetais. Federal University of Goiás; 2001:116.
8. Ciconini G. Caracterização de frutos e óleo de polpa de macaúba dos biomas Cerrado e Pantanal do estado de Mato Grosso do Sul, Brasil. Brazil. Universidade Católica Dom Bosco; 2012:127.

9. Pacheco CAT, Silva AC, Silva EMS, et al. Macaúba's pulp oil as collector in apatite froth flotation. 14th International Mineral Processing Symposium. Turquia. 2014:359-366.

10. Silva AC, Silva EMS, Machado AM, et al. Using two alternative vegetable oil's as collector in apatite froth flotation. VIII Beneficiation of Phosphates, Cape Town, South Africa. 2018:38-46.

11. Brandão PRG, Caires LG, Queiroz DSB. Vegetable lipid oil-based collectors in the flotation of apatite ores. Minerals Engineering. 1994;7(7):917-925.

12. Mata CED. Desempenho de ácidos graxos na flotação seletiva de apatita proveniente do minério fosfático de Angico dos Dias-BA. Brazil. Federal University of Ouro Preto; 2019.

13. Pacheco CAT. Análise técnica e econômica do uso do óleo da polpa de macaúba (Acrocomia Aculeta) como coletor na flotação. Brazil. Federal University of Goiás; 2016:120.

14. Bergmann JC, Tupinambá DD, Costa OYA, et al. Biodiesel production in Brazil and alternative biomass feedstocks. Renewable and Sustainable Energy Reviews. 2013;21:411-420.

15. Santos E, Oliveira J. Utilização de óleo de jojoba como coletor alternativo na flotação seletiva entre apatita e calcite. Rio de Janeiro. 2012:1-2.

16. Silva AC, Silva EMS, Silva TC, et al. Apatite microflotation using pequi oil. Transactions - Institution of Mining and Metallurgy. Section C. Mineral Processing \& Extractive Metallurgy. 2015;124(4):233-239.

17. Silva AC, Silva EMS, Rocha TWP. Microflotação de apatita utilizando óleo da castanha de macaúba (Acrocomia Aculeata) como coletor. Tecnologia em Metalurgia, Materiais e Mineração. 2015;12(2):146152.

18. Silva AC, Moraes ILA, Silva EMS, et al. Jatropha curcas L. Oil Selectivity in Froth Flotation. International Journal of Biological, Biomolecular, Agricultural, Food and Biotechnological Engineering. 2016;10:562-568.

19. Vieira M. Lédo PGS, Lima RFS, et al. Flotação de calcita a partir de óleos vegetais regionais saponificados como agentes coletores. VI Congresso Brasileiro de Engenharia Química em Iniciação Científica. Campinas. 2005:1-5. 